\title{
Improved Chitin and Chitosan Production from Black Tiger Shrimp Shells Using Salicylic Acid Pretreatment
}

\author{
Nguyen Van Toan \\ School of Biotechnology, International University, Ho Chi Minh City, Vietnam \\ Vietnam National University, Ho Chi Minh City, Vietnam
}

\begin{abstract}
Shrimp chitin and chitosan with improved characteristics were isolated from black tiger shrimp waste pretreated with $0.04 \mathrm{M}$ Salicylic acid for ten hours. The pretreated shrimp shells could be efficiently demineralized and deproteinized at ambient temperature using $0.680 \mathrm{M} \mathrm{HCl}$ and $0.620 \mathrm{M} \mathrm{NaOH}$, respectively. The duration of the treatments was 8 hours, the ash and protein residues in the final chitosan were about $0.48 \%$ and $0.51 \%$ respectively; the viscosity was $4800 \mathrm{cps}$; the solubility was up to $98 \%$. In comparison with treatment at ambient temperature $\left(30^{\circ} \mathrm{C}\right)$ without pretreatment, the chemical consumption, the duration of the treatment, ash and protein residues was reduced to $75-20 \%$, whereas viscosity and absence of insolubles improved by a factor of 2.5 .
\end{abstract}

Keywords: Chitin, chitosan, membrane, pretreated, Salicylic acid, wound healing management.

\section{INTRODUCTION}

Chitin and chitosan are the structural components in the cuticles of crustacean, insects, mollusk and in the cell wall of fungi and plant pathogens (Suwalee, 2002) [1]. Reportedly, chitin and chitosan have various biological functions, for instance, antimicrobial activity; wound healing, especially on the proliferative phase and matrix formation.

Since the early eighties, chitin and its derivatives have been used for various biomedical purposes especially in skin and wound management products in Japan [2]. Though several standard chemical procedures have been widely used to produce chitin and chitosan utilizing shrimp shell waste as raw material, there is not much information about how to improve the production process so as to produce chitosan with consistent quality especially high solubility, high viscosity and high stability in degree of deacetylation while ash content ash and protein are as low as possible.

Salicylic acid is a keratolytic agent that softens the hyperkeratotic areas by dissolving the intra-cellular matrix and enhancing shedding of scales. This acid has been widely used in the removal of all types of human and animal skin warts using a technique of cauterization wherein slaked lime is applied to wart and then the surface of wart is scratched by using the stem of betel leaf, in general [3]. It has been shown that Salicylic acid softens keratin, loosens cornified epithelium and causes swelling even of viable cells. In a test of percutaneous absorption through skin of hairless rat as a good example, the data showed that Salicylic acid softens the horny layer and enhances the permeability of the stratum corneum.

Exoskeletal chitin-protein complexes give protection against chitinases and mild alkaline conditions. The more strongly the protein is bound to chitin, the harder for $\mathrm{NaOH}$

\footnotetext{
*Address correspondence to this author at the School of Biotechnology, International University, Ho Chi Minh City, Vietnam; Fax: +84-837244271; E-mail: nvtoan@hcmiu.edu.vn
}

to penetrate and to detach the protein from the solid shell material. Salicylic acid seems to weaken the exoskeletal complex matrix of protein resulting in the removal of a protein fraction that otherwise remains bound to the solid waste. As a consequence, this acid helps allowing $\mathrm{NaOH}$ solution to easily penetrate and facilitate the breakdown of protein components in the matrix.

This paper describes experiments to determine the suitable process for production of improved characteristics of chitin and chitosan from black tiger shrimp shells for various aspects of chitosan application.

\section{MATERIALS AND METHODS}

The black tiger shrimp shells used in this study were obtained from a local shrimp processing factory, Southern part of Vietnam. The shells which were pretreated with $0.04 \mathrm{M}$ Salicylic acid was demineralized with $0.680 \mathrm{M} \mathrm{HCl}$ solution $(1: 5 \mathrm{w} / \mathrm{v})$ at ambient temperature, $28-32^{\circ} \mathrm{C}$ for $8 \mathrm{hrs}$. The residue was washed and soaked in tap water for 6-8 hours. It was then dewatered and deproteinized with $0.620 \mathrm{M}$ $\mathrm{NaOH}$ solution $(1: 5 \mathrm{w} / \mathrm{v})$ at ambient temperature for $16 \mathrm{hrs}$.

The chitin obtained from the above processes was deacetylated in $12.5 \mathrm{M} \mathrm{NaOH}(1: 5 \mathrm{w} / \mathrm{v})$ solution at $65^{\circ} \mathrm{C}$ for $18 \mathrm{hrs}$ for chitosan isolation.

The process scheme for chitin/chitosan production under this study is shown in Fig. (1). After deacetylation, the chitosan was washed and dried in sunlight and assayed for moisture content, ash content, protein content, degree of deacetylation, viscosity, solubility, turbidity and molecular weight.

The protein content in the chitosan sample was determined using the micro-biuret method [4]. The degree of deacetylation was determined by first derivative ultraviolet (UV) spectrophotometry [5]. Weight average molecular weight was determined by gel permeation chromatography (Waters GPC) with a differential refractometer detector [6]. Dextrans of various molecular weights ranging from $9.9 \mathrm{x}$ $10^{3}$ to $2 \times 10^{6}$ were used as standards. Ash content was 
determined by the standard AOAC method [7]. Various physico-chemical criteria were investigated for chitosan in a $1 \%$ solution in $0.35 \mathrm{M}$ acetic acid. Turbidity was assessed using a turbidimeter (Model 2100P, HACH Company, USA) and viscosity by a Brookfield Model DV - VII + Viscometer. Solubility was measured using the transglucosidase method [8]: the $\mathrm{pH}$ of $50 \mathrm{ml} 1 \%(\mathrm{w} / \mathrm{v})$ chitosan solution was adjusted to 4.8 with $30 \%(\mathrm{w} / \mathrm{v})$ sodium acetate and mixed with Transglucosidase L-500 (Genencor International, $500 \mu \mathrm{l}$ ). After incubating at $60^{\circ} \mathrm{C}$ for $24 \mathrm{hrs}$, the insoluble material was collected by filtration using a pre-weighed Whatman $\mathrm{GF} / \mathrm{C}$ filter paper $(1.2 \mu \mathrm{m})$. The filter paper was dried and weighed and the amount of insolubles was calculated from its weight gain. Turbidity was assessed using a turbidimeter (Model 2100P, HACH Company, USA) and viscosity by a Brookfield Model DV-VII+ viscometer.

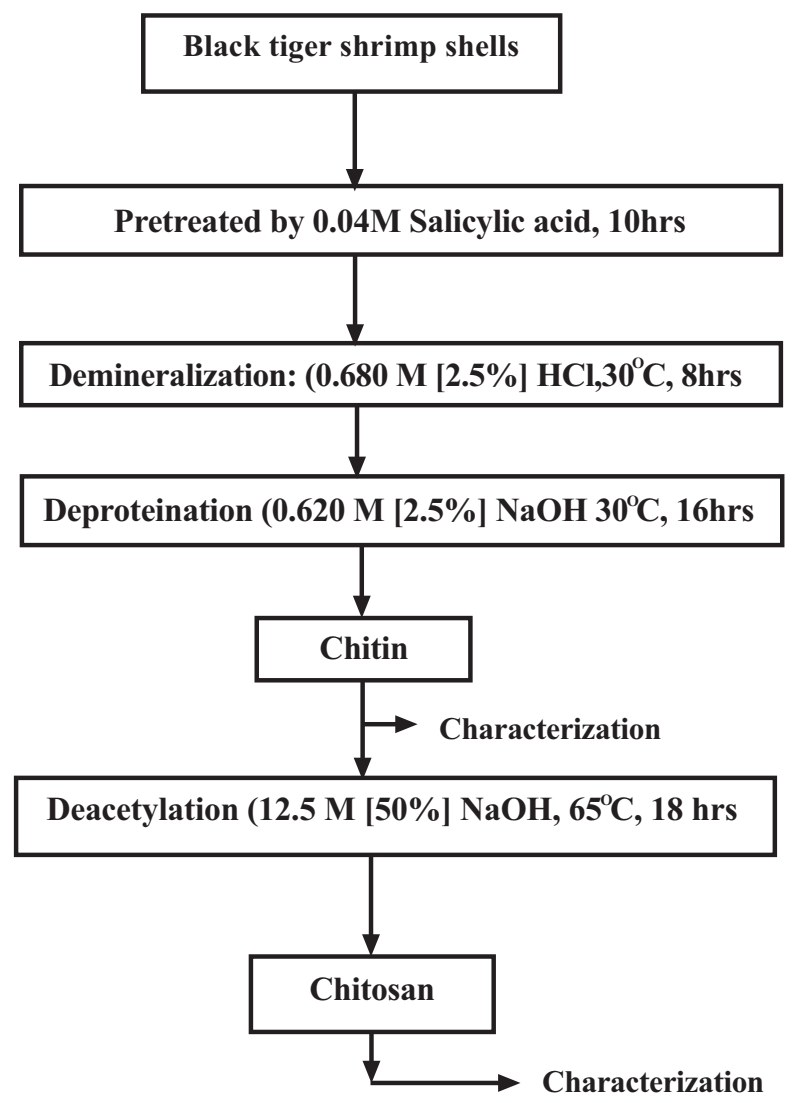

Fig. (1). The revised process for the production of chitin and chitosan under this study.

The reproducibility of chitosan was determined by storing chitosan in $0.1 \mathrm{M}$ acetic acid for a period of 60 days at temperature of $28^{\circ} \mathrm{C}-30^{\circ} \mathrm{C}$ according to method of Stevens [9]. In this study, the molecular weight was measured every ten days.

Chitosan membrane was tested for its thickness using a Mitutoyo micrometer. Tensile strength and elongation at break were measured for sample pieces of $10 \pm 1 \mu \mathrm{m}$ thickness $(10 \times 15 \mathrm{~mm})$ with a tensile tester, model Synergie 200, Adamel Lhmargy Co. Moisture sorption of chitosan membrane was measured at $84 \%$ relative humidity (Nunthanid et al., 2001) [10]. Gel swelling index was determined by the method reported by Chen et al. (1994) [11]. Permeation of sodium salicylate through chitosan membranes was assessed using a Franz diffusion cell $(5 \mathrm{~cm}$ effective area of diffusion) at $30 \pm 2^{\circ} \mathrm{C}$. The solute concentration in the receptor compartment was calculated from its absorbance at $296 \mathrm{~nm}$ using a spectrophotometer. Permeation coefficient was calculated by applying Fick_s law. Lysozyme activity was assayed by the amount of reducing sugar generated by incubation of chitosan membrane $\left(1 \mathrm{~cm}^{2}\right)$ or chitosan powder $(0.05 \mathrm{~g})$ in a solution of $1.25 \mathrm{mg}$ lysozyme in $25 \mathrm{ml} 0.2 \mathrm{M}$ phosphate buffer $\mathrm{pH} 7$. The mixture was incubated at $37^{\circ} \mathrm{C}$. The reducing sugar was determined after $24 \mathrm{~h}$ of incubation by the Schales method (Imoto and Yagishita, 1971) [12].

All data are expressed as means \pm standard deviation of representative of similar test carried out in triplicate. Statistical differences in cell number were determined by student's t-test in which, $\mathrm{p}<0.005$ was considered statistical significant.

\section{RESULTS AND DISCUSSION}

The general characteristics of chitin and chitosan produced from the pretreated shrimp shells by Salicylic acid are listed in Table $\mathbf{1 .}$

Table 1. Characteristics of Chitin and Chitosan Produced from Pretreated Shrimp Shells by Dilute Salicylic Acid

\begin{tabular}{|c|c|c|}
\hline Characteristics & Chitin & Chitosan \\
\hline Ash content $(\%)^{*}$ & $0.52 \pm 0.03$ & $0.48 \pm 0.20$ \\
\hline Protein content $(\%)^{* *}$ & $0.55 \pm 0.04$ & $0.51 \pm 0.25$ \\
\hline Solubility (\%) & & $98 \pm 0.03$ \\
\hline Degree of deacetylation (\%) & & $89 \pm 0.35$ \\
\hline Molecular Weight (daltons $\times 10^{6}$ ) & & 1.71 \\
\hline Viscosity (cps) & & $4850 \pm 300$ \\
\hline Turbidity (NTU) ${ }^{* * *}$ & & $22 \pm 5$ \\
\hline
\end{tabular}

*The ash content of the original shells was $24.5 \%$

** The protein content of the original shell was $24 \%$

*** Chitosan $1 \%(\mathrm{w} / \mathrm{v})$ dissolved in $0.35 \mathrm{~mol} \mathrm{~L}^{-1}$ acetic acid (NTU: Nephelometric Turbidity Unit).

The viscosity of the Salicylic acid pretreated chitosan in solution is closed to $5000 \mathrm{cps}$ compared with $2650 \mathrm{cps}$ of control chitosan produced using common methods.

Data on the depolymerization of chitosan, of which, was storing in $0.1 \mathrm{M}$ acetic acid for a period of 60 days at a temperature of $28^{\circ} \mathrm{C}-30^{\circ} \mathrm{C}$ has been compared with studies of our colleagues in Bioprocess Program laboratory in Bangkok on comparison of storage of chitosan in acetic acid and in formic acid [9]. As expected, the produced chitosan using the proposed procedures under this study showed a reduction of less than $85 \%$ in Molecular weight (MW) in the $60^{\text {th }}$ day. Data on the rate of chitosan degradation in $0.1 \mathrm{M}$ acetic acid is shown in the Table 2.

The produced chitosan under the revised procedure was used for preparation of chitosan membrane and testing its characteristics, of which tensile strength, moisture sorption as well as the permeability constant are especially explored. As shown in Fig. (2) and Table 3, the chitosan membranes 

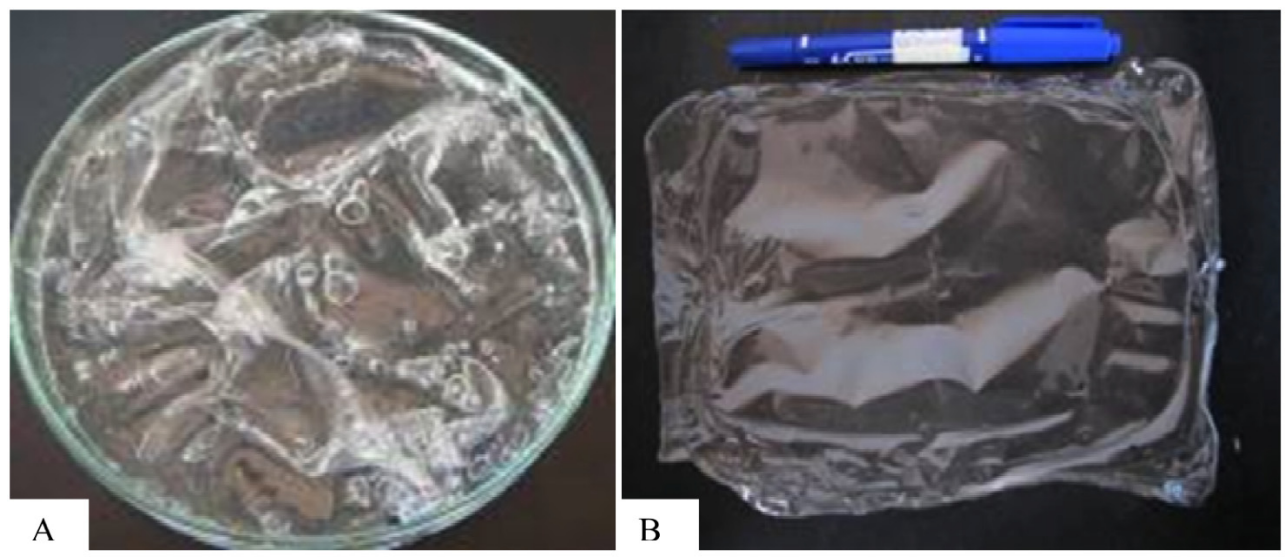

Fig. (2). Appearance of chitosan membranes before and after detaching (A) and drying in the lab (B) at ambient temperature

were transparent and colorless. The average thickness of the membranes was $10 \pm 1 \mu \mathrm{m}$.

Table 2. Rate of Chitosan Degradation in 0.1 M Acetic Acid

\begin{tabular}{|c|c|c|c|c|c|c|c|}
\hline Time (Days) & $1^{\text {st }}$ & $10^{\text {th }}$ & $20^{\text {th }}$ & $30^{\text {th }}$ & $40^{\text {th }}$ & $50^{\text {th }}$ & $60^{\text {th }}$ \\
\hline Mw (Daltons $\left.\times \mathbf{1 0}^{6}\right)$ & 1.73 & 1.55 & 1.45 & 1.25 & 1.15 & 0.90 & 0.26 \\
\hline
\end{tabular}

Table 3. Characteristics of Chitosan Membrane from Chitosan of Deacetylation of $89 \%$

\begin{tabular}{|c|c|}
\hline Chitosan Membrane & Characteristic Index \\
\hline \hline Crystallinity & $0.75 \pm 0.2$ \\
\hline Tensile strength & $2.35 \pm 0.4$ \\
\hline Moisture sorption & $70 \pm 7.0$ \\
\hline Permeability & $45.00 \pm 3$ \\
\hline
\end{tabular}

Notes: Before performing the test, the chitosan membrane was preconditioned at $25^{\circ} \mathrm{C}$, relative humidity of $50 \%$ for 24 hours.

Data of the current research are similar to those of Stevens [9] and Trung TS [6], provided that some characteristics of chitosan such as degree of deacetylation, solubility, turbidity and viscosity are essentially important parameters and should be taken into account before starting making chitosan membrane for further applications.

\section{CONCLUSIONS}

The collected data demonstrate that the high and consistent quality of chitosan produced from black tiger shrimp shells could be obtained by pre-treating the shells using dilute Salicylic acid. Shrimp chitosan produced in this way could be used as a good source of raw material for further post processes of chitosan amongst other applications.

\section{ACKNOWLEDGEMENT}

The author would like to express his thanks to the International University, Vietnam National University, Ho Chi Minh City for the generous financial support.

\section{REFERENCES}

[1] Suchiva K, Chandrkrachang S, Methacanon P, Peter MG, Eds. Proceedinggs of the $5^{\text {th }}$ Asia Pacific Chitin and Chitosan Symposium \& Exhibition. Bangkok, Thailand 2002.

[2] Brian C, Zikakis J P, and Sandford P, Eds. In: Beschitin, E, Ed. Clinical application of chitin artificial skin. Elsevier: Amsterdam 1992.

[3] Sarfaraz KN. Handbook of Bioequivalence Testing, Drugs and the pharmaceutical Sciences. USA: Pinehurst North Carolina Press 2007; vol. 171.

[4] Uragami T, Kurita K, Fukamizo T, Eds. Chitin and chitosan in lifescience. Tokyo: Kodansha Scientific Ltd 2001.

[5] Muzzarelli RAA, Rocchetti, Determination of the degree of deacetylation of chitosan by first derivative ultraviolet spectrophotometry. J Carbohydr Polym 1985; 5: 461-72.

[6] Trung TS, Thein-Han WW, Qui NT, Ng CH, Stevens WF. Functional characteristics of shrimp chitosan and its membranes as affected by the degree of deacetylation. Bioresour Technol 2006; 97(4): 659-63.

[7] AOAC. Official methods of analysis, $14^{\text {th }}$ ed. Washington, DC: Association of Official Analytical Chemists 1984; pp. 64-90.

[8] Hein S, Ng CH, Stevens WF. Quantification and characterization of insoluble chitinous materials in viscous chitosan solutions. Biotechnol Lett 2003; 25: 863-8.

[9] Suchiva K, Chandrkrachang S, Methacanon P, Peter MG, Eds. Production and storage of high quality chitosan from shrimp shell, crab and fungus. Proceedinggs of the 5th Asia Pacific Chitin and Chitosan Symposium \& Exhibition. Bangkok, Thailand 2002.

[10] Nunthanid J. Puttipipatkhachorn S Yamamoto K, Peck GE Physical properties and molecular behavior of chitosan films. Drug Dev Ind Pharm 2001; 27: 143-57.

[11] Chen R H, Lin J H, Yang M H. Relationships between the chain flexibilities of chitosan molecules and the physical properties of their cast films. Carbohydr Polym 1994; 24: 41-46.

[12] Imoto T, Yagishita K. A simple activity measurement of lysozyme. J Agric Biol Chem 1971; 35: 1154-56.

[13] Toan NV, Ng CH, Aye KN, et al. Production of high-quality chitin and chitosan from preconditioned shrimp shells. J Chem Technol Biotechnol 2006; 81(7): 1113-8. 